\title{
Characterization of the occupied shells by the hermit crab Clibanarius vittatus (Decapoda, Diogenidae) at Baixio Mirim tideflat, Guaratuba Bay, southern Brazil
}

\author{
SARA R. SAMPAIO and SETUKO MASUNARI \\ Departamento de Zoologia, Universidade Federal do Paraná, Centro Politécnico \\ Caixa Postal 19020, 81541-990 Curitiba, PR, Brasil \\ Manuscript received on May 19, 2009; accepted for publication on August 31, 2009
}

\begin{abstract}
A characterization of the occupied shells by the hermit crab Clibanarius vittatus was carried out. Hermit crabs were collected in the intertidal zone, during the low spring tide monthly from April 2005 to March 2006. They were sexed and their cephalothoracic shield length (CL) was measured. Shells were identified, dried, weighed and the aperture length (AL) and width (AW) were measured. 1187 crabs were collected (949 males, 216 females and 22 intersexes), which occupied 12 species of gastropod shells. Stramonita haemastoma, Olivancillaria urceus and Dorsanum moniliferum made up $96.55 \%$ of the total shell species. Male hermit crabs attained significantly larger sizes than females; therefore, males occupied a wider spectrum of shells in size and weight. A stronger correlation ratio was obtained between CL and AW of S. haemastoma. Last whorl with a rounded shape and a spacious inner area is a common feature of all shell species most frequently occupied by this hermit crab where it occurs. The successful establishment of $C$. vittatus at Baixio Mirim is mainly due to the appropriately shaped and wide range of size of S. haemastoma shells that were most often occupied by the hermit crabs of the studied population.
\end{abstract}

Key words: Guaratuba Bay, shell availability, shell occupation, shell size and shape.

\section{INTRODUCTION}

Hermit crabs are anomuran crustaceans that use empty shells of gastropods as a shelter. These shells can be acquired from the habitat if empty and available; if not, by removing dead or dying mollusks, once hermit crabs are unable to dislodge alive gastropods from their shells (Rittschof 1980, Bertness 1981, Tricarico and Gherardi 2006). The gastropod shells perform several important roles in the life of these crabs, mainly the protection of their uncalcified abdomen against eventual mechanical shocks and dryness.

The use of the specific shell species by a hermit crab is firstly related to the availability of these shells in the environment (see revision in Vance 1972, Turra

Correspondence to: Sara Regina Sampaio

E-mail: sararsp@yahoo.com.br and Leite 2001, Meireles et al. 2003). When this availability is restricted in the habitat, hermit crabs are compelled to occupy shells that are not always appropriate in size, form or integrity, and this restriction affects reproduction (Childress 1972, Bertness 1981, Hazlett 1989, Bertini and Fransozo 2000, Hazlett et al. 2005, Turra 2005), growth (Markham 1968, Bertness 1981, Osorno et al. 1998, Bertini and Fransozo 2000) and body morphology (Turra and Leite 2002).

Secondly, the occupation of a specific shell is influenced either by the interactions among hermit crabs, such as intra-specific competition for the shell, or by other resources (Bertness 1980, 1981, Gherardi and Nardone 1997, Dominciano and Mantelatto 2004, Sant'Anna et al. 2006b), coexistence of different hermit crabs species (Kellog 1977, Bertness 1980, Gherardi and Nardone 
1997, Floeter et al. 2000, Turra 2003, Sant'Anna et al. 2006b), predation (Bertness 1982, Rotjan et al. 2004), presence of gastropods in the community (Bertness 1980, Turra and Leite 2001, Sant'Anna et al. 2006a), previous experience (Hazlett 1993, Hahn 1998, Meireles et al. 2008, Alcaraz and Kruesi 2009) and formation of aggregations (Hazlett 1981, Turra and Leite 2000a). The hermit crab ability in detecting odours of died or dying gastropods was also reported (Kratt and Rittschof 1991, Chiussi et al. 2001).

Likewise, morphometric characteristics of shells influence their occupation by hermit crabs. Among these characteristics are weight (Hahn 1998, Dominciano and Mantelatto 2004, Turra and Leite 2004), size (Bertini and Fransozo 2000, Turra and Leite 2004), opening size (Botelho and Costa 2000, Bertini and Fransozo 2000, Sant'Anna et al. 2006a) and architecture and volume (Gherardi and Nardone 1997, Floeter et al. 2000, Shih and Mok 2000).

Clibanarius vittatus (Bosc, 1802) has a wide geographical distribution in western Atlantic, from the eastern of the United States to West Indies, including Gulf of Mexico, and from Venezuela to southern Brazil, in Santa Catarina State (Melo 1999). In spite of the wide distribution, the ecological aspects of this species were only reported in the USA in North and South Carolina, Florida and Gulf of Mexico, and in Brazil these aspects are restricted to the São Paulo State coast (Turra 2003, 2005, Turra and Leite 2001, 2002, 2004, Sant'Anna et al. 2006a, b). The present study is the first research about the relationships of the hermit crab C. vittatus and its occupied shell from the Guaratuba Bay, Paraná State, southern Brazil.

\section{MATERIALS AND METHODS}

Baixio Mirim is a $6.300 \mathrm{~m}^{2}$ tideflat located within Guaratuba Bay and isolated from the continent by a narrow channel of $15-20 \mathrm{~m}$ width. Most of its substrate is covered by the smooth cordgrass Spartina alterniflora Loisel, but it is also provided with sandy and muddy surface especially in the bordering areas. In spite of urban influence, this tideflat is inhabited by hundreds of fiddler crabs that constitute the main preys for sea birds that land on the sandbanks during low tides (Masunari et al. 2005).
Hermit crabs occur individually or in groups of 5-10 crabs either in the vegetated areas or in non-vegetated ones in Baixio Mirim tideflat, from where they were collected during low spring tides, monthly from April/2005 to March/2006. Each monthly sample consisted of nearly a hundred crabs collected with the following shell size frequency distribution: $25 \%$ of individuals occupying small shells, $50 \%$ medium and $25 \%$ big ones. This procedure aimed to avoid collections biased towards more visible shells because hermit crabs have a gregarious habit, and a sampling based on the area or CPUE would be improper. Furthermore, such number was sufficient or more than sufficient to represent populations of hermit crabs in other studies in the Brazilian coast (Fransozo and Mantelatto 1998, Floeter et al. 2000, Turra and Leite 2000b, 2001, Sant'Anna et al. 2006a).

Hermit crabs were packed in plastic bags and kept in a thermal box; at the laboratory, they were preserved in freezer until their handling. They were extracted by hand from the occupied shells but, when necessary, it was done with the help of a small vice. After this, the crabs were preserved in alcohol $70 \%$ while shells were dried up indoors for $24 \mathrm{~h}$. Hermit crabs were identified, sexed, and the length (CL) of the cephalothoracic shield was obtained with a $0.01 \mathrm{~mm}$ precision digital caliper. Sexes were identified according to the position of genital openings; intersex individuals had both male and female genital openings. Empty shells were identified and weighted (SWE) with an electronic scale of $0.01 \mathrm{~g}$ precision, and their aperture length (AL) and width (AW) were measured with the same caliper. Only the most occupied shells were used for comparative analysis and, therefore, those having less than 5\% occupation were excluded.

Krukal-Wallis was used for statistical comparison of the dimensions among the different shell species, and for comparison of these dimensions in the occupied shells by different sexes (these dimensions had not a normal distribution), the Dunn's test was used to locate the source of variations. The $\chi^{2}$ was used to compare the shell occupation frequencies between males and females. Correlation Indices of Spearman were calculated for all correlations among dimensions: only complete and unbroken shells were used in this analysis. All tests had a confidence of $95 \%$. 


\section{RESULTS}

A total of 1187 hermit crabs Clibanarius vittatus were collected, out of which 949 were males, 204 non-ovigerous females, 12 ovigerous females and 22 intersexes. They occupied 12 species of gastropod shells, with the highest frequency of occupation in Stramonita haemastoma (Linnaeus, 1767) with $64.61 \%$, followed by Olivancillaria urceus (Röding, 1798) with $26.47 \%$, and Dorsanum moniliferum (Valenciennes, 1834) with $5.48 \%$. The remainder shells were occupied with less than $1 \%$ each one, and altogether they did not sum up 4\% - Achatina fulica (Bowdich, 1822), Buccinanops lamarckii (Kiener, 1834), Cymatium parthenopeum (Von Salis, 1793), Chicoreus (Siratus) senegalensis (Gmelin, 1791), Olivancillaria steeriae (Reeve, 1850), Olivancillaria uretai Klappenbach, 1965, Semicassis granulatum (Born, 1778), Polinices hepaticus (Röding, 1798) and Zidona dufresnei (Donovan, 1823) (Table I). Only S. haemastoma, O. urceus and D. moniliferum (more than $95 \%$ of occupation) were used for comparative analysis.

The shell species differed significantly in their weight $(\mathrm{H}=116.37, \mathrm{p}<0.0001)$ and dimensions (AL: $\mathrm{H}=314.85 ; \mathrm{p}<0.0001$. AW: $\mathrm{H}=59.96 ; \mathrm{p}<0.0001)$ (Fig. 1), showing that each one has its own characteristics. In this context, D. moniliferum had the smallest dimensions $(\mathrm{SWE}=3.74 \pm 1.24 \mathrm{~g} ; \mathrm{AL}=16.04 \pm$ $2.33 \mathrm{~mm}$; AW $=8.32 \pm 1.11 \mathrm{~mm})$, while $O$. urceus the largest weight and length $(\mathrm{SWE}=8.16 \pm 4.05 \mathrm{~g} ; \mathrm{AL}$ $=25.82 \pm 3,99 \mathrm{~mm} ; \mathrm{AW}=8.51 \pm 1.42 \mathrm{~mm})$, and $S$. haemastoma the largest aperture width ( $\mathrm{SWE}=6.62 \pm$ $4.14 \mathrm{~g} ; \mathrm{AL}=18.77 \pm 5.91 \mathrm{~mm} ; \mathrm{AW}=9.88 \pm 2.67 \mathrm{~mm})$ (Table II).

Male hermit crabs ranged from 2.97 to $11.56 \mathrm{~mm}$ CL, females from 2.97 to $8.24 \mathrm{~mm}$, and intersexes from 3.76 to $9.45 \mathrm{~mm}$. The hermit crabs' CL average ranged according to the shell species occupied by them $(\mathrm{H}=$ 54.91; $\mathrm{p}<0.0001)$ : those living inside the shells of $S$. haemastoma $(\mathrm{CL}=6.11 \pm 1.39)$ had highest $\mathrm{CL}$, while those of $O$. urceus $(\mathrm{CL}=5.54 \pm 0.90 \mathrm{~mm})$ and D. moniliferum $(\mathrm{CL}=5.17 \pm 0.90 \mathrm{~mm}$ ) had close $\mathrm{CL}$ average without statistical difference (Fig. 2). Dimensions of the shells occupied by males were statistically dissimilar to those occupied by females. On the other hand, the shells occupied by intersexes were similar to those occupied by males; this relation is the same for non-ovigerous and ovigerous females. AL and AW of the shells occupied by the latter ones had no significant difference from those occupied by intersexes (KruskalWallis, $\mathrm{p}<0.05$ ) (Table III).

The three most frequently occupied shell species were common among these sexes. Furthermore, a pattern in the shell use was observed: S. haemastoma shells were occupied by almost all hermit crab sizes, $O$. urceus by medium-sized crabs and $D$. moniliferum by smaller ones. However, each sex occupied these shells with distinct frequencies: $29.29 \%$ males used O. urceus, while $15.58 \%$ females and $18.18 \%$ intersexes did it. In contrast, only $4.52 \%$ males, $8.33 \%$ females and $13.64 \%$ intersexes occupied D. moniliferum (Fig. 3).

In the correlation analyses between hermit crabs $\mathrm{CL}$ and the shell species dimensions, S. haemastoma showed the higher correlation indices, followed by $O$. urceus and D. moniliferum. Shell SWE was the dimension with the highest correlation indices with hermit crab CL. Among the hermit crabs occupying O. urceus and S. haemastoma shells, males presented higher correlation indices than females, but the opposite was found for D. moniliferum shell users (Table IV).

\section{DISCUSSION}

The total number of shell species occupied by $C$. vittatus $(=12)$ in the present study is similar to that of populations living in shallow waters of the southeast coast of Brazil (Negreiros-Fransozo et al. 1991, Reigada and Santos 1997, Sant'Anna et al. 2006a). However, this number can increase up to 16 in tropical areas such as Florida, USA (Lowery and Nelson 1988).

The dominant occupation of the gastropod shell $S$. haemastoma by $C$. vittatus observed in Baixio Mirim tideflat was also reported in previous studies on populations coming from Galveston Island, USA (Fotheringham 1975), and from São Paulo State (Negreiros-Fransozo et al. 1991, Reigada and Santos 1997, Sant'Anna et al. 2006a), excepting in Turra and Leite (2002), who found Chicoreus senegalensis (Gmelin, 1791) as the most frequently occupied shell by this hermit crab.

The relationships between the hermit crab populations and the occupied shells reveal that some shell features are more important than others for crab occu- 
TABLE I

Clibanarius vittatus. Absolute and relative frequencies of occupation of 12 shell species by male, female and intersex hermit crabs.

\begin{tabular}{l|c|c|c|c|c|c|c|c|c}
\hline \multirow{2}{*}{ Shell species } & \multicolumn{2}{|c|}{$\begin{array}{c}\text { Male } \\
\text { hermit crabs }\end{array}$} & \multicolumn{2}{c|}{$\begin{array}{c}\text { Female } \\
\text { hermit crabs }\end{array}$} & \multicolumn{2}{c|}{$\begin{array}{c}\text { Intersex } \\
\text { hermit crabs }\end{array}$} & \multicolumn{2}{|c|}{ Total } & $\chi^{2}$ \\
\hline & $\mathrm{N}$ & $\%$ & $\mathrm{~N}$ & $\%$ & $\mathrm{~N}$ & $\%$ & $\mathrm{~N}$ & $\%$ & \\
\hline Stramonita haemastoma & 591 & 62.29 & 161 & 74.54 & 15 & 68.18 & 767 & 64.61 & n.s. \\
\hline Olivancillaria urceus & 278 & 29.29 & 33 & 15.58 & 3 & 13.64 & 314 & 26.47 & $*$ \\
\hline Dorsanum moniliferum & 43 & 4.53 & 18 & 8.33 & 4 & 18.18 & 65 & 5.48 & n.s. \\
\hline Semicassis granulatum & 9 & 0.94 & 1 & 0.46 & & & 10 & 0.84 & n.s. \\
\hline Buccinanops lamarckii & 7 & 0.74 & 2 & 0.93 & & & 9 & 0.76 & n.s. \\
\hline Polinices hepaticus & 7 & 0.74 & & & & & 7 & 0.59 & n.s. \\
\hline Chicoreus senegalensis & 5 & 0.53 & & & & & 5 & 0.42 & n.s. \\
\hline Cymatium parthenopeum & 5 & 0.53 & & & & & 5 & 0.42 & n.s. \\
\hline Zidona dufresnei & 2 & 0.21 & & & & & 2 & 0.17 & n.s. \\
\hline Achatina fulica & 1 & 0.10 & & & & & 1 & 0.08 & n.s. \\
\hline Olivancillaria steeriae & & & 1 & 0.46 & & & 1 & 0.08 & n.s. \\
\hline Olivancillaria uretai & 1 & 0.10 & & & & & 1 & 0.08 & n.s. \\
\hline \hline TOTAL & 949 & 100.0 & 216 & 100.00 & 22 & 100.00 & 1187 & 100.00 & \\
\hline
\end{tabular}

$\mathrm{N}=$ absolute number; $*=$ significant; n.s. $=$ not significant.

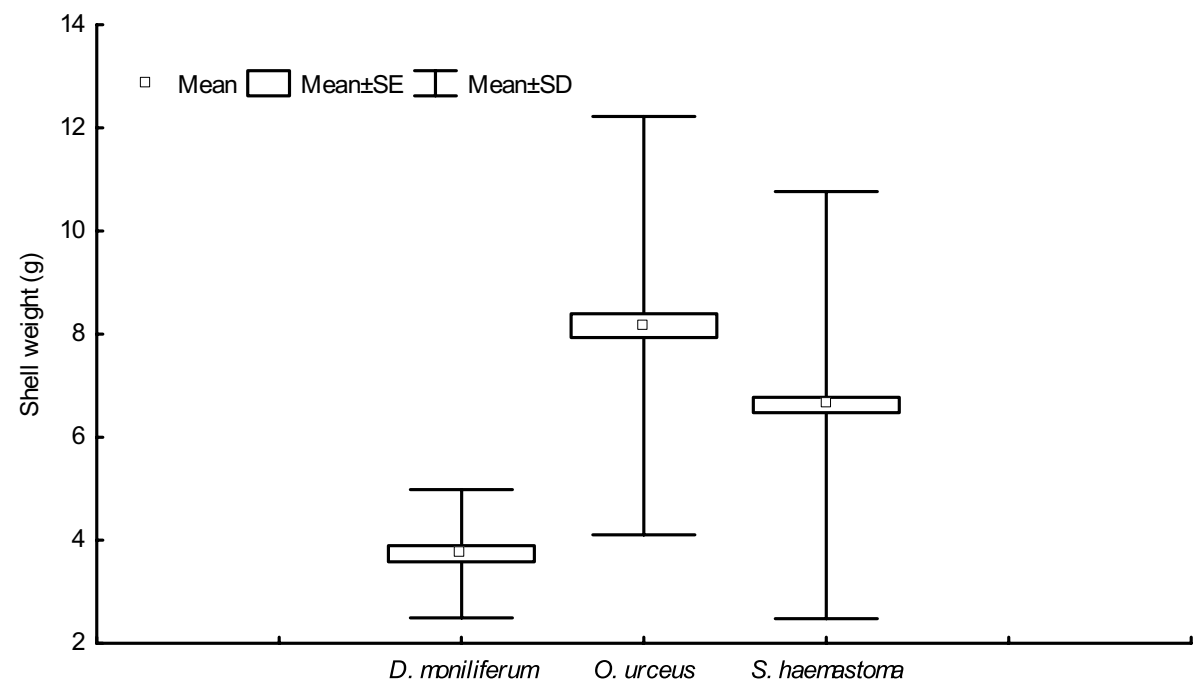

Fig. 1 - Clibanarius vittatus. Mean, standard deviation and standard error of the shell weight of the gastropod species more occupied by hermit crabs.

pation. Turra and Leite (2002), studying C. vittatus, demonstrated that the shell dimension was more important than its volume. Furthermore, in the study carried by Floeter et al. (2000) with Calcinus tibicen (Herbst, 1971) and Clibanarius antillensis Stimpson, 1859, the shell volume was more important than its weight. Bertini and Fransozo (2000) and Shih and Mok (2000), studying Petrochirus diogenes (Linnaeus, 1758) and
Calcinus latens (Randall, 1839), respectively, considered that the shell was the most important feature for occupation, and more recently Masunari et al. (2008) observed that Isocheles sawayai (Forest and Saint Laurent, 1968), living in infralittoral waters of southern Brazil, occupied predominantly $O$. urceus, a gastropod that has a heavy shell, and it may act as an anchor for this filter feeding hermit crab. 
TABLE II

Clibanarius vittatus and shell species most often occupied by the hermit crabs. Dunn's multiple comparisons test $(\mathrm{P}<\mathbf{0 . 0 5})$ with significant differences in the comparison of morphometric variables between pairs of shell species and average $C L$ of the hermit crabs that occupied these shells.

\begin{tabular}{l|c|c|c|c}
\hline Shell species pairs compared & SWE $(\mathrm{g})$ & AL $(\mathrm{mm})$ & AW $(\mathrm{mm})$ & CL $(\mathrm{mm})$ \\
\hline D. moniliferum $\times$ O. urceus & $* * *$ & $* * *$ & n.s. & n.s. \\
\hline D. moniliferum $\times$ S. haemastoma & $* * *$ & $* *$ & $* * *$ & $* * *$ \\
\hline O. urceus $\times$ S. haemastoma & $* * *$ & $* * *$ & $* * *$ & $* * *$ \\
\hline
\end{tabular}

SWE $=$ shell weight; $\mathrm{AL}=$ aperture length; $\mathrm{AW}=$ aperture width; $\mathrm{CL}=$ cephalothoracic shield length. $* *=\mathrm{p}<0.01 ; * * *=\mathrm{p}<0.001 ;$ n.s. $=$ not significant.

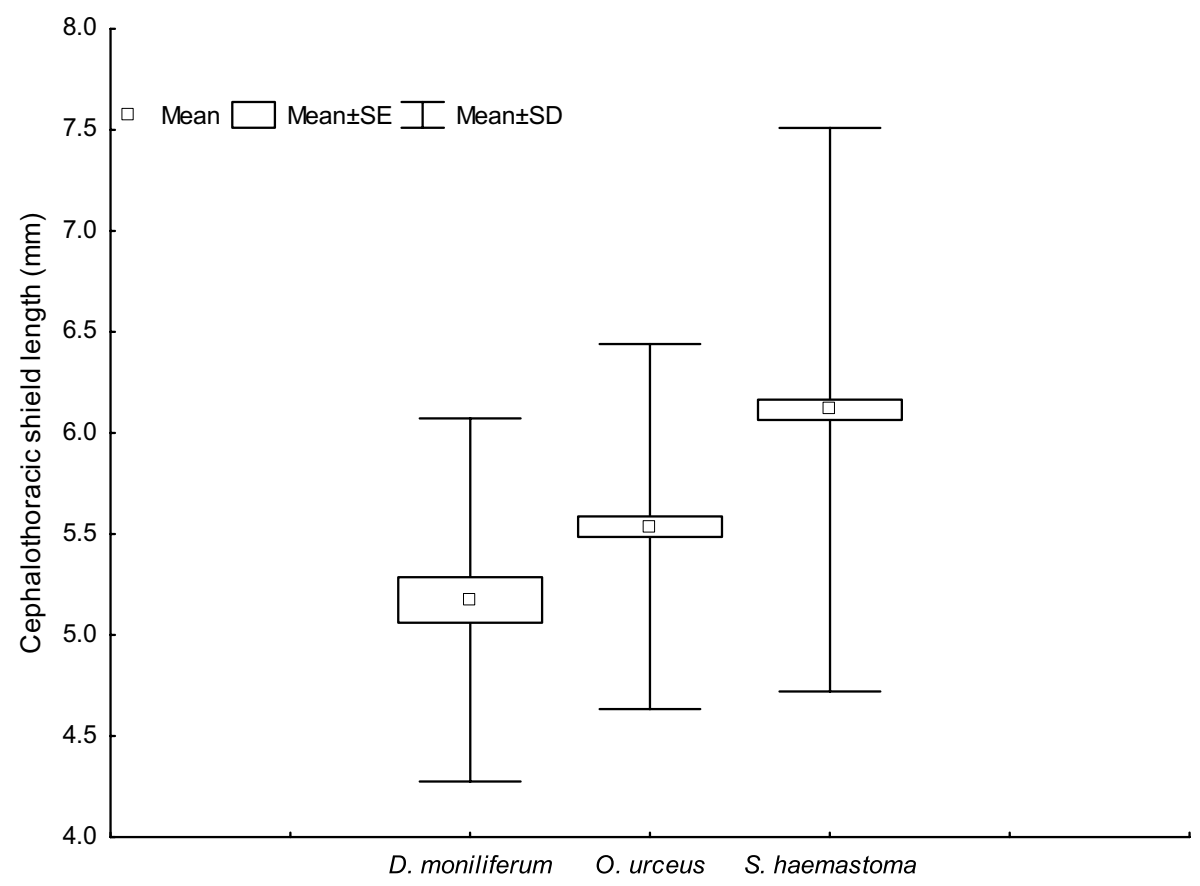

Fig. 2 -Clibanarius vittatus. Mean, standard deviation and standard error of the hermit crabs' cephalothoracic shield that occupied three more frequent shell species.

\section{TABLE III}

Shell species occupied by the hermit crab Clibanarius vittatus.

Dunn's multiple comparisons $(p<0.05)$ between the hermit crab sexes in the morphometric variables of occupied shells $(H=157.53)$.

\begin{tabular}{l|c|c|c}
\hline & SWE $(\mathrm{g})$ & AL $(\mathrm{mm})$ & AW $(\mathrm{mm})$ \\
\hline Females $\times$ Ovigerous females & n.s. & n.s. & n.s. \\
\hline Females $\times$ Intersexes & $* * *$ & $* *$ & $* * *$ \\
\hline Females $\times$ Males & $* * *$ & $* * *$ & $* * *$ \\
\hline Ovigerous females $\times$ Intersexes & $*$ & n.s. & n.s. \\
\hline Ovigerous females $\times$ Males & $* * *$ & $* *$ & $*$ \\
\hline Intersexes $\times$ Males & n.s. & n.s. & n.s.
\end{tabular}

$\mathrm{SWE}=$ shell weight; $\mathrm{AL}=$ aperture length; $\mathrm{AW}=$ aperture width. $*=\mathrm{p}<0.05$; $* *=\mathrm{p}<0.01 ; * * *=\mathrm{p}<0.001 ;$ n.s. $=$ not significant. 


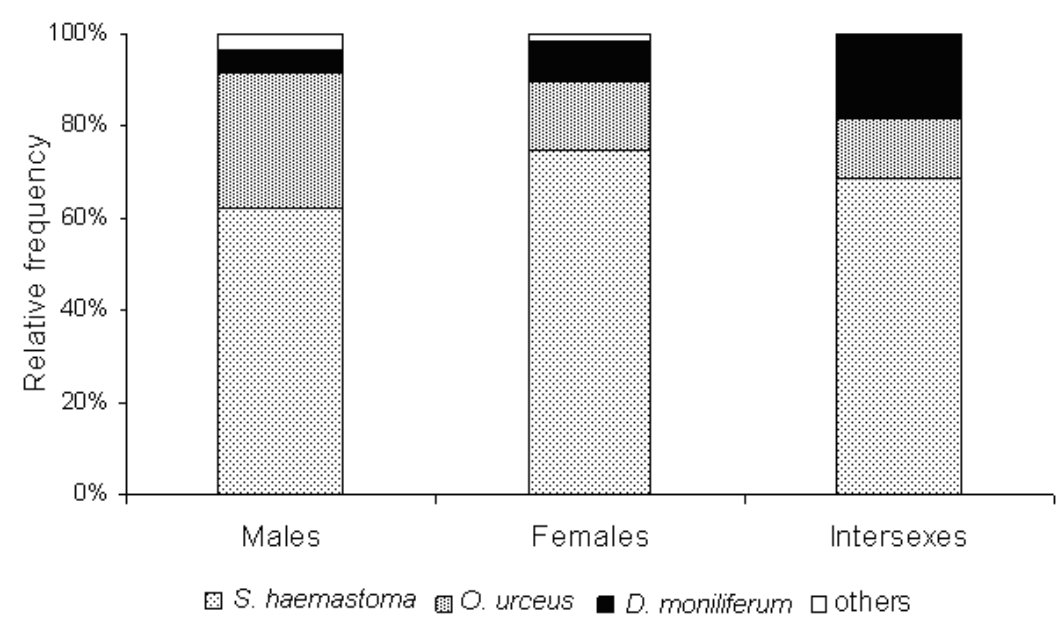

Fig. 3 -Clibanarius vittatus. Relative frequencies of occupied shells by males, females and intersexes.

There is a common architectural feature among the shell species occupied mainly by populations of $C$. vittatus living along the western Atlantic Ocean coast: the last whorl is globe-shaped and spacious, with shell aperture measuring $50-70 \%$ of the total length (Table V; see figures in Rios 1975 and Abbott and Dance 1998). According to Floeter et al. (2000), the preference for shells with enlarged last whorl and higher internal volume by hermit crabs of the genus Clibanarius is related to the maintenance of a humid microhabitat, especially during the exposed condition due to the low tide.

Stramonita haemastoma occurs in the western Atlantic Ocean coast from North Carolina, USA, to southern Brazil (Rios 1975). The almost complete overlapping in the geographical distribution of S. haemastoma and C. vittatus (compare to Melo 1999) can indicate that the shell availability is the main reason for occupying in higher frequency this shell species. Moreover, Turra and Leite (2002) demonstrated through laboratory experiment that $S$. haemastoma had been chosen among other shell species, which means that $C$. vittatus has a specific preference. The most frequently occupied shell Chicoreus senegalensis observed by these authors in the environment could be due to competition with other sympatric hermit crab species. Alongside the western Atlantic Ocean coast, where S. haemastoma is present, this hermit crab can occupy preferably another species, such as Littorina irrorata (Say, 1822) in North and South Carolina, USA (Mitchell 1975, Young 1979), and Melongena corona (Gmelin, 1791) in Florida, USA
(Lowery and Nelson 1988) (Table V). The significant occupation of other shell species with similar morphology to S. haemastoma (last whorl relatively enlarged than others) may indicate that the shell architecture is more important than shell species in the selection by C. vittatus.

Another indication that $S$. haemastoma is the suitable shell due to its shell architecture and/or general shape, is the highest correlation indices obtained between the shell dimensions and its occupier. Turra and Leite (2002) and Sant'Anna et al. (2006a) reported a strong correlation in the relationships of $\mathrm{CL} \times \mathrm{SL}$ (shell length) and $\mathrm{CL} \times \mathrm{AL}$.

The dissimilar frequencies in the occupation of the shell species among males, females and intersexes are difficult to explain. As C. vittatus males attain larger sizes than females (Lowery and Nelson 1988, Sant'Anna et al. 2006a), an eventual intra-specific competition for the best shells would result in a large proportion of males occupying S. haemastoma shells. However, the opposite was observed: about $62 \%$ males occupied this shell species, while about $75 \%$ females did it. It is possible to conjecture that females' requirement in occupying $S$. haemastoma is the need to accommodate their eggs inside the spacious whorl of this shell species. The dominance of males in the occupation of $O$. urceus shell, the second most occupied one, supports this assumption (see Table I).

In spite of absence of an exhaustive list of gastropod species that could potentially supply $C$. vittatus with 
TABLE IV

Clibanarius vittatus. Statistics for morphometric relationships $(\mathbf{p}<0.05)$ between the hermit crab sexes and the three most frequently occupied shell species.

\begin{tabular}{c|l|l|c}
\hline Shell species & Relation & \multicolumn{1}{|c}{ Equation } & $\mathrm{r}$ \\
\hline $\begin{array}{c}\text { S. haemastoma } \\
\text { Males }\end{array}$ & $\mathrm{CL} \times \mathrm{SWE}$ & $\mathrm{LnSWE}=-0.92+2.16 \mathrm{LnCL}$ & 0.8119 \\
$\mathrm{n}=591$ & $\mathrm{CL} \times \mathrm{AL}$ & $\mathrm{LnAL}=0.39+1.11 \mathrm{LnCL}$ & 0.7849 \\
Females & $\mathrm{CL} \times \mathrm{AW}$ & $\mathrm{LnAW}=0.23+0.97 \mathrm{LnCL}$ & 0.8311 \\
$\mathrm{n}=151$ & $\mathrm{CL} \times \mathrm{AL}$ & $\mathrm{LnSWE}=-0.6+1.62 \mathrm{LnCL}$ & 0.6849 \\
& $\mathrm{CLAL} \times \mathrm{AW}$ & $\mathrm{LnAW}=0.48+0.82 \mathrm{LnCL}$ & 0.6068 \\
\hline O. urceus & $\mathrm{CL} \times \mathrm{SWE}$ & $\mathrm{LnSWE}=-0.63+2.04 \mathrm{LnCL}$ & 0.7338 \\
Males & $\mathrm{CL} \times \mathrm{AL}$ & $\mathrm{LnAL}=0.88+0.72 \mathrm{LnCL}$ & 0.7739 \\
$\mathrm{n}=278$ & $\mathrm{CL} \times \mathrm{AW}$ & $\mathrm{LnAW}=0.37+0.75 \mathrm{LnCL}$ & 0.7475 \\
Females & $\mathrm{CL} \times \mathrm{SWE}$ & $\mathrm{LnSWE}=-0.50+1.73 \mathrm{LnCL}$ & 0.6751 \\
$\mathrm{n}=33$ & $\mathrm{CL} \times \mathrm{AL}$ & $\mathrm{LnAL}=0.94+0.61 \mathrm{LnCL}$ & 0.7462 \\
& $\mathrm{CL} \times \mathrm{AW}$ & $\mathrm{LnAW}=0.41+0.66 \mathrm{LnCL}$ & 0.6491 \\
\hline D. moniliferum & $\mathrm{CL} \times \mathrm{SWE}$ & $\mathrm{LnSWE}=0.08+0.89 \mathrm{LnCL}$ & 0.4985 \\
Males & $\mathrm{CL} \times \mathrm{AL}$ & $\mathrm{LnAL}=1.03+0.26 \mathrm{LnCL}$ & 0.3752 \\
$\mathrm{n}=43$ & $\mathrm{CL} \times \mathrm{AW}$ & $\mathrm{LnAW}=\mathrm{Ln} 0.76+0.24 \mathrm{LnCL}$ & 0.4052 \\
Females & $\mathrm{CL} \times \mathrm{SWE}$ & $\mathrm{LnSWE}=\mathrm{Ln}(-0.60)+1.65 \mathrm{LnCL}$ & 0.6851 \\
$\mathrm{n}=17$ & $\mathrm{CL} \times \mathrm{AL}$ & $\mathrm{LnAL}=\mathrm{Ln}(0.80)+0.56 \mathrm{LnCL}$ & 0.4796 \\
& $\mathrm{CL} \times \mathrm{AW}$ & $\mathrm{LnAW}=\mathrm{Ln} 0.42+0.68 \mathrm{LnCL}$ & 0.7187 \\
\hline
\end{tabular}

$\mathrm{CL}=$ cephalothoracic shield length; $\mathrm{SWE}=$ shell weight; $\mathrm{SL}=$ shell length; $\mathrm{SW}=$ shell weight; $\mathrm{AL}=$ aperture length; $\mathrm{AW}=$ aperture width; $\mathrm{r}=$ correlation indices of Spearman.
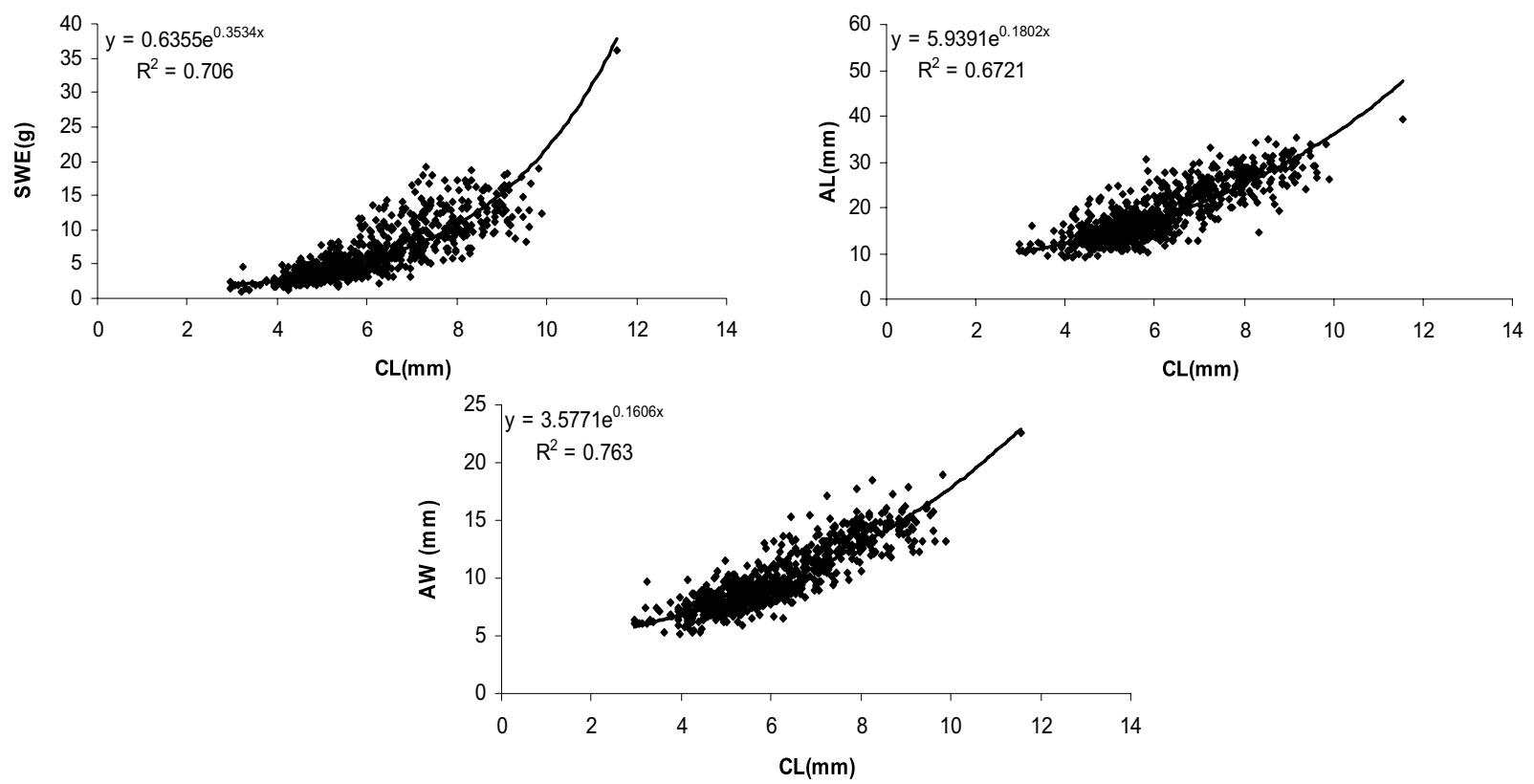

Fig. 4 - Clibanarius vittatus. Dispersion plots between hermit crab cephalothoracic shield length (CL) and variables of the most frequently occupied shell - S. haemastoma. $(\mathrm{SWE}=$ shell weight; $\mathrm{AL}=$ shell aperture length; $\mathrm{AW}=$ shell aperture width). 
TABLE V

Clibanarius vittatus. Localities where the hermit crabs was reported, total number and most frequently occupied shell species.

\begin{tabular}{l|l|c|l}
\hline \multicolumn{1}{c|}{ Locality } & $\begin{array}{c}\text { Most frequently occupied } \\
\text { shell species by the } \\
\text { hermit crab }\end{array}$ & $\begin{array}{c}\text { No. of } \\
\text { occupied shell } \\
\text { species }\end{array}$ & \multicolumn{1}{c}{ Reference } \\
\hline North Carolina, USA & Littorina irrorata & 5 & Mitchell (1975) \\
\hline South Carolina, USA & Littorina irrorata & 6 & Young (1979) \\
\hline Gulf Coast, USA & Stramonita haemastoma & 8 & Fotheringham (1975) \\
\hline Florida, USA & Melongena corona & 16 & Lowery and Nelson (1988) \\
\hline São Sebastião, Brazil & Chicoreus senegalensis & 9 & Turra (personal communication) \\
\hline Ubatuba, Brazil & Stramonita haemastoma & 2 & Negreiros-Fransozo et al. (1991) \\
\hline São Vicente, Brazil & Stramonita haemastoma & 13 & Sant'Anna et al. (2006a) \\
\hline Guaratuba, Brazil & Stramonita haemastoma & 12 & Present study \\
\hline
\end{tabular}

empty shells, it is possible to infer that this hermit crab can find plenty of shelters at Baixio Mirim tideflat, either in abundance or in size spectrum. The morphometric dimensions of the three mostly occupied shells - S. haemastoma, O. urceus and D. moniliferum - that showed positive correlation with hermit crab size support this assumption.

\section{ACKNOWLEDGMENTS}

We are grateful to Prof. Dr. Osmar Domaneschi (in memoriam) and Dr. Adolpho Birman from the Departamento de Zoologia, Universidade de São Paulo for the confirmation of the gastropod shell identification. To SIMEPAR for the data of air temperature. To the colleague Kirstern Lica Follmann Haseyama for the help with sample handlings. To Prof. Dr. Eva DalMolin from Universidade Federal do Paraná for the English revision. This is Contribution number 1724 of the Departamento de Zoologia, Universidade Federal do Paraná.

\section{RESUMO}

A caracterização das conchas ocupadas pelo ermitão Clibanarius vittatus (Bosc, 1802) foi realizada. Os ermitões foram coletados de abril/2005 a março/2006, na zona intertidal, durante a maré baixa de sizígia. Os ermitões tiveram o sexo reconhecido e foram medidos no comprimento do escudo cefalotorácico. As conchas foram identificadas, pesadas depois de secas e medidas no comprimento e na largura da abertura. Foram coletados 1187 ermitões (949 machos, 216 fêmeas e 22 intersexos) que ocuparam 12 espécies de conchas de gastrópodes. Stramonita haemastoma, Olivancillaria urceus e
Dorsanum moniliferum perfizeram $96,55 \%$ do total das conchas ocupadas. Ermitões machos atingiram tamanhos significativamente maiores do que as fêmeas; entretanto ocuparam um maior espectro de conchas em tamanho e peso. Fortes índices de correlação foram obtidos para a relação entre o escudo cefalotorácico dos ermitões e a largura da abertura de $S$. haemastoma. A última espira espaçosa e de formato globoso é um aspecto comum das conchas mais frequentemente ocupadas pelo presente ermitão em todos os locais de sua ocorrência. O sucesso no estabelecimento de $C$. vittaus no Baixio Mirim é devido principalmente ao formato e à amplitude de tamanhos das conchas de $S$. haemastoma, as quais são mais frequentemente ocupadas pelos ermitões da população estudada.

Palavras-chave: Baía de Guaratuba, disponibilidade de conchas, ocupação de conchas, tamanho e formato da concha.

\section{REFERENCES}

AbBott RT AND DANCE SP. 1998. Compendium of seashells. El Cajon: Odyssey, 411 p.

Alcaraz G And KRUesi K. 2009. The role of previous shell occupancy in the wild on laboratory shell choice by hermit crab Calcinus californiensis. Mar Fresh Behav Physiol 42: 55-62.

BERTINI G AND Fransozo A. 2000. Patterns of shell utilization in Petrochirus diogenes (Decapoda, Anomura, Diogenidae) in the Ubatuba region, São Paulo, Brazil. J Crust Biol 20(3): 468-473.

BERTNESS MD. 1980. Shell preferences and utilization patterns in littoral hermit crabs of the Bay of Panama. J Exp Mar Biol Ecol 48: 1-16. 
BERTNESS MD. 1981. Interference, exploitation, and sexual components of competition in a tropical hermit crab assemblage. J Exp Mar Biol Ecol 49: 189-202.

BERTNESS MD. 1982. Shell utilization, predation pressure, and thermal stress in Panamanian hermit crabs: an interoceanic comparison. J Exp Mar Biol Ecol 64: 159-187.

Botelho AZ And Costa AC. 2000. Shell occupancy of the intertidal hermit crab Clibanarius erythropus (Decapoda, Diogenidae) on São Miguel (Azores). Hydrobiologia 440: 111-117.

CHILDRESS JR. 1972. Behavioral ecology and fitness theory in a tropical hermit crab. Ecology 53(3): 960-964.

Chiussi R, Dias H, RitTschof D AND Forward JR RB. 2001. Orientation of the hermit crab Clibanarius antillensis: effects of visual and chemical cues. J Crust Biol 21(3): 593-605.

Dominciano LCC And Mantelatto FLM. 2004. The influence of Shell species and size in the shell selection pattern of Paguristes tortugae (Decapoda, Diogenidae) from Anchieta Island (Ubatuba, Brazil). Iheringia, Ser Zool 94(4): 425-428.

Floeter SR, NALESSo RC, Rodrigues MMP AND TURRA A. 2000. Patterns of shell utilization and selection in two sympatric hermit crabs (Anomura, Diogenidae) in south-eastern Brazil. J Mar Biol Ass UK 80: 1053-1059.

FotheRINGHAM N. 1975. Structure of seasonal migrations of the littoral hermit crab Clibanarius vittatus. J Exp Mar Biol Ecol 18: 47-53.

Fransozo A And Mantelatto FLM. 1998. Populations structure and reproductive period of the tropical hermit crab Calcinus tibicen (Decapoda: Diogenidae) in the region of Ubatuba, São Paulo, Brazil. J Crust Biol 18(4): $738-745$.

GHERARDi F AND NARDONE F. 1997. The question of coexistence in hermit crabs: population ecology of a tropical intertidal assemblage. Crustaceana 70: 608-629.

HAHN DR. 1998. Hermit crab shell use pattern: response to previous Shell experience and to water flow. J Exp Mar Biol Ecol 184: 35-51.

HAZLETT BA. 1981. The behavior ecology of hermit crabs. Ann Rev Ecol Syst 12: 1-22.

HAZLETT BA. 1989. Mating success of male hermit crabs in shell generalist and shell specialist species. Behav Ecol Sociobiol 25: 119-128.

Hazlett BA. 1993. Past experience and shell use in hermit crabs: shell Exchange behavior. Mar Behav Physiol 22(2): 89-96.
Hazlett BA, Rittschof D And BACH CE. 2005. The effects of shell size and coil orientation on reproduction in female hermit crabs, Clibanarius vittatus. J Exp Mar Biol Ecol 323(2): 93-99.

Kellog CW. 1977. Coexistence in a hermit crab species ensemble. Biol Bull 153: 133-144.

Kratt CM AND RitTschof D. 1991. Peptide attraction of hermit crabs Clibanarius vittatus Bosc: roles of enzymes and substrates. J Chem Ecol 17(12): 2347-2366.

LOWERY WA AND NELSON WG. 1988. Population ecology of the hermit crab Clibanarius vittatus (Decapoda: Diogenidae) at Sebastian Inlet, Florida. J Crust Biol 84(4): $548-556$.

MARKHAM BA. 1968. Notes on growth-patterns and shell utilization of the hermit crab Pagurus bernhardus (L.). Ophelia 5: 189-205.

Masunari S, Dissenha N AND FAlCÃo RC. 2005. Crescimento relativo e destreza dos quelípodos de Uca maracoani (Latreille) (Crustacea, Decapoda, Ocypodidae) no Baixio Mirim, Baía de Guaratuba, Paraná, Brasil. Rev Bras Zool 22(4): 974-983.

Masunari S, Fontanelli AM And SAMPaio SR. 2008. Morphometric relationships between the hermit crab Isocheles sawayai (Forest and Saint Laurent) (Crustacea, Anomura, Diogenidae) and its shell from southern Brazil. The open Mar Biol J 2: 13-20.

Meireles AL, Biagi R and Mantelatto FL. 2003. Gastropod Shell availability as a potential resource for the hermit crab infralittoral fauna of Anchieta Island (SP), Brazil. Nauplius 11(2): 99-105.

Meireles AL, Biagi R and Mantelatto FL. 2008. Influence of prior experience on shell selection by the white spotwrist hermit crab Pagurus criniticornis (Crustacea: Paguridae). Hydrobiologia 605: 259-263.

Melo GAS. 1999. Manual de identificação dos Crustacea Decapoda do litoral brasileiro: Anomura, Thalassinidea, Palinuridea, Astacidea. São Paulo: Plêiade, 551 p.

MitChell KA. 1975. An analysis of shell occupation by two sympatric species of hermit crab. I. Ecological factors. Biol Bull 149: 205-213.

Negreiros-Fransozo ML, Fransozo A and Hebling NJ. 1991. Estrutura populacional e determinação do tamanho da concha em 4 espécies de ermitões (Crustacea, Decapoda, Anomura) do litoral paulista. Biotemas 4(2): 135-148.

OSORNO JL, FERnANDEZ-CASILlas L AND RODRIGUEZJUAREZ C. 1998. Are hermit crabs looking for light and 
large shell? Evidence from natural and field induced shell exchanges. J Exp Mar Biol Ecol 222: 163-173.

REIGADA AL AND SANTOS S. 1997. Biologia e relação com a concha em Clibanarius vittatus (Bosc, 1802) (Crustacea, Diogenidae) em São Vicente, SP, Brasil. Arq Biol Tecnol 40(4): 941-952.

RIOS EC. 1975. Brazilian marine mollusks iconography. Rio Grande: Fundação Universidade do Rio Grande, 330 p.

RitTSCHOF D. 1980. Chemical attraction of hermit crabs and other attendants to simulated gastropod predation sites. J Chem Ecol 6(3): 665-676.

RotJAn RD, BLUM J AND LEWIS SM. 2004. Shell choice in Pagurus longicarpus hermit crabs: does predation threat influence shell selection behavior? Behav Ecol Sociobiol 56: $171-176$.

SANT'ANNA BS, ZANGRANDE CM, REIGADA ALD AND PINHEIRO MAA. 2006a. Shell utilization pattern of the hermit crab Clibanarius vittatus (Crustacea, Anomura) in a estuary at São Vicente, State of São Paulo, Brazil. Iheringia, Ser Zool 96(2): 261-266.

SANT'ANNA BS, ZANGRANDE CM, REIGADA ALD AND SEVERINO-Rodrigues E. 2006b. Spatial distribution and shell utilization in three sympatric hermit crabs at non-consolidated sublittoral of estuarine-bay complex in São Vicente, São Paulo, Brazil. Rev Biol Mar Oceanogr 41(2): 141-146.

SHIH H AND MOK H. 2000. Utilization of shell resources by the hermit crabs Calcinus latens and Calcinus gaimardii at Kenting, southern Taiwan. J Crust Biol 20(4): 786-795.

TRICARICO E AND GHERARDI F. 2006. Shell acquisition by hermit crabs: which tactic is more efficient? Behav Ecol Sociobiol 60: 492-500.
TURRA A. 2003. Shell condition and adequacy of three sympatric intertidal hermit crab populations. J Nat Hist 37: 1781-1795.

TURRA A. 2005. Reproductive behavior of intertidal hermit crabs (Decapoda, Anomura) in southeastern Brazil. Rev Bras Zool 22(2): 313-319.

TURRA A AND LEITE FPP. 2000a. Clustering behavior of hermit crabs (Decapoda, Anomura) in an intertidal rocky shore at São Sebastião, southeastern Brazil. Rev Bras Biol 60: $39-44$.

TURra A AND Leite FPP. 2000b. Population biology and growth of three sympatric species of intertidal hermit crabs in south eastern Brazil. J Mar Biol Ass UK 80: 1061-1069.

TURRA A AND LEITE FPP. 2001. Shell utilization patterns of a tropical rock intertidal hermit crab assemblage: I. The case of Grande Beach. J Crust Biol 21(2): 393-406.

TURRA A AND LEITE FPP. 2002. Shell utilization patterns of a tropical intertidal hermit crab assemblage. J Mar Biol Ass UK 82: 97-107.

TURRA A AND LeITE FPP. 2004. Shell-size selection by the intertidal sympatric hermit crabs. Mar Biol 145: 251-257.

VANCE RR. 1972. Competition and mechanisms of coexistence in three sympatric species of intertidal hermit crabs. Ecology 53: 1062-1074.

YounG AM. 1979. Differential utilization of gastropod shells by three hermit crab species in North Inlet, South Carolina, USA. Crustaceana 5(suppl): 101-104. 